\title{
АКТУАЛЬНІ АСПЕКТИ ДІАГНОСТИКИ І ВЕДЕННЯ АМБУЛАТОРНОГО ПАЦІЄНТА 3 ЦУКРОВИМ ДІАБЕТОМ (ЗА ДОСВІДОМ ХОРВАТІЇ ТА СЛОВЕНІї)
}

\author{
сл. С. Бабінець, Ю. Я. Коцаба \\ Тернопільський національний медичний університет імені І. Я. Горбачевського МОЗ України
}

РЕзЮМЕ. Через поширеність і хронічні ускладнення, що супроводжують цукровий діабет (ЦД), він $є$ значною проблемою охорони здоров'я, а також фінансовим і організаційним тягарем для людей і держави. Вартість медичного супроводу пацієнта з ЦД 2-го типу в п'ять разів перевищує середні витрати на одного пацієнта в популяції.

Мета - проаналізувати алгоритми діагностики і ведення пацієнта з цукровим діабетом 2-го типу за європейськими протоколами (Хорватії та Словенії) у цілому і на прикладі клінічної ситуації.

Обговорення. Хворі на ЦД 2-го типу потребують всебічної допомоги із дотриманням принципів догляду за пацієнтами із хронічними захворюваннями в сімейній медицині. Керуючи хворим на ЦД, сімейний лікар виконує наступні важливі завдання: запобігти виникненню ЦД за допомогою заходів пропаганди здорового способу життя; виявити осіб з високим ризиком ЦД і намагатися відтермінувати початок хвороби; виявити ЦД шляхом раннього розпізнавання пацієнта з високим ризиком його виникнення; зменшити виникнення можливих ускладнень і смертність від ЦД шляхом адекватного раціонального лікування.

Висновки. Цукровий діабет $\epsilon$ важливою проблемою для громадського здоров'я через високий рівень захворюваності і все більшу поширеність. Лікування пацієнтів із діабетом - це командна робота. Вона вимагає узгодження багатьох зацікавлених сторін у системі охорони здоров'я. Сімейний лікар керує та координує догляд за пацієнтом, який, з усіма його очікуваннями, бажаннями та уявленнями про хворобу і життя з нею, $є$ центром цього комплексу заходів. Ведення пацієнта з цукровим діабетом повинно відповідати наступним рекомендаціям: клінічна мета лікування хворих на діабет - метаболічна регуляція та профілактика хронічних ускладнень. Мета, орієнтована на пацієнта - це його якість життя і задоволеність наданою допомогою. Найважливішим є удосконалення способу життя, чого досягти найскладніше.

КлючовІ СловА: цукровий діабет; критерії діагностики; ведення пацієнтів; метаболічна регуляція; спосіб життя.

Вступ. За епідеміологічними даними, понад 30 млн дорослих в Європейському Союзі страждають на цукровий діабет (ЦД). Поширеність ЦД збільшилась 37,6 \% у 2003 р. до 8,6 \% у 2006 р. Очікується, що найближчим часом ЦД уразить більше 10 \% населення Європи [2]. В Україні відбувається зростання кількості хворих на ЦД, яка вже перевищує відмітку 2 млн осіб. ЦД стає неінфекційною пандемією у світі [1]. За оцінкою експертів ВОО3, у світі прогнозується приріст числа хворих, що страждають на ЦД, до 300 млн осіб. У Хорватії поширеність ЦД у віковій групі від 18 до 65 років становить 6,1 \%, а у старшій - від 15 до $20 \%$. Поширеність у віковій групі від 20 до 80 років становить 9,2 \% [3]. За поширеністю ЦД Словенія відповідає статистиці європейських країн [4].

Через поширеність і хронічні ускладнення, що супроводжують ЦД, він $\epsilon$ значною проблемою охорони здоров'я, а також фінансовим і організаційним тягарем для людей і держави. Вартість медичного супроводу пацієнта з ЦД 2-го типу в п'ять разів перевищує середні витрати на одного пацієнта в популяції. Причини - частіші госпіталізації, в основному через серцево-судинні захворювання. Хворий на ЦД часто відвідує кабінет сімейної медицини, такі візити тривають найдовше, прово- диться більше процедур, консультується у більшої кількості фахівців. Ця хвороба $є$ обтяжливою для кожного пацієнта, оскільки є соціальним і економічним тягарем для нього і його сім'ї, причиною ранньої або стійкої втрати працездатності, а також ранньої смерті [6].

Мета - проаналізувати алгоритми діагностики і ведення пацієнта з цукровим діабетом 2-го типу за європейськими протоколами (Хорватії та Словенії) у цілому і на прикладі клінічної ситуації.

Основна частина. ЦД - це група захворювань обміну речовин із такою загальною характерною ознакою як гіперглікемія, що виникає внаслідок дефектів секреції інсуліну. Існує кілька видів захворювання: 1) ЦД 1-го типу (раніше називався «інсулінозалежним» діабетом), 2) ЦД 2-го типу (раніше його називали «неінсулінонезалежним» діабетом), 3) гестаційний ЦД (перше виявлення під час вагітності), 4) інші види діабету $[1,8]$.

ЦД 1-го типу $\epsilon$ результатом аутоімунного або ідіопатичного руйнування $\beta$-клітин підшлункової залози (ПЗ) та наслідком основного дефіциту інсуліну. Він виникає в ранньому дитинстві та юності при першому тяжкому клінічному прояві гіперглікемії. Лікування проводиться на рівні стаціонарної ланки. Сімейний лікар бере участь у виявленні 
Огляди літератури, оригінальні дослідження, погляд на проблему, випадок з практики, короткі повідомлення захворювання та у подальшому спостереженні у формі спільної відповідальності за лікування і догляд за хронічними ускладненнями.

Гестаційний ЦД визначається тим, що він уперше виникає під час вагітності, найчастіше у другому триместрі, через підвищення діабетогенних гормонів і нечутливості до інсуліну. Гіперглікемія відповідає критеріям, встановленим для цього типу діабету (глюкоза в плазмі натще $\geq 5,1$ ммоль/л). Обстеження на цей тип ЦД проводять гінекологи та сімейні лікарі, вперше між 23-м та 28-м тижнями вагітності. Пацієнти, у яких не діагностовано ЦД, мають пройти пероральний тест на толерантність до глюкози (ПТТГ). Тут порогові значення для встановлення діагнозу є нижчими за ПТТГ для виявлення ЦД 1-го і 2-го типів (>8,5 ммоль/л). Пацієнтку лікує ендокринолог/діабетолог. Сімейний лікар піклується про пацієнта після пологів, як такого, що перебуває в зоні більш високого ризику ЦД.

Інші типи ЦД включають захворювання порушення зовнішньої функції ПЗ, різні генетичні порушення, а також ЦД як наслідок прийому медикаментів чи інших речовин [5].

Діабет 2 типу - це найпоширеніший тип діабету, який уражає багато органів через хронічну гіпоглікемію, а також $\epsilon$ фактором ризику серцево-судинних захворювань і ускладнень, пов'язаних 3 порушенням мікроциркуляції. Процедура діагностики визначається наявністю або відсутністю симптомів і значенням глюкози натще або в стандартизованому тесті на ПТТГ (із 75 г глюкози після голодування пацієнта). Оскільки захворювання може мати тривалий доклінічний перебіг, важливим $€$ раннє виявлення, оскільки воно зменшує або затримує виникнення хронічних ускладнень. Важливим $\epsilon$ виявлення предіабету або порушення регуляції глюкози, оскільки в цих умовах підвищується ризик розвитку ЦД. Поширеність захворювання збільшується у людей віком старше 40 р., найчастіше його діагностують в осіб, яким 60 і 70 р. [4].

Якісна допомога вимагає командного підходу в практиці сімейної медицини, включаючи необхідні консультації з іншими фахівцями. У європейських країнах роль сімейного лікаря в боротьбі з ЦД різна. Це залежить від позиції сімейного лікаря в національній системі охорони здоров'я, освіти лікаря та членів його команди. Кількість консультацій з фахівцями залежить від клінічного прояву ЦД і коморбідних станів, на які страждає пацієнт.

Пацієнти потребують всебічної допомоги із дотриманням принципів догляду за хронічними хворими в сімейній медицині. Керуючи хворим на ЦД, сімейний лікар виконує наступні важливі завдання: запобігати виникненню ЦД за допомогою заходів пропаганди здорового способу життя; виявляти осіб із високим ризиком ЦД і намага-

тися відтермінувати початок хвороби; виявляти ЦД шляхом раннього розпізнавання пацієнта 3 високим ризиком його виникнення; зменшувати виникнення можливих ускладнень і смертність від ЦД шляхом адекватного раціонального лікування [6].

Серед причинних факторів виникнення ЦД 2-го типу суттєву роль можуть відігравати генетично детерміновані дефекти, хоча їх механізми не зовсім з'ясовані. Постійна гіперглікемія виникає на трьох рівнях: ПЗ не виробляє достатню кількість інсуліну для задоволення потреб організму, стійкість периферійних тканин до інсуліну, посилення вироблення печінкової глюкози. На ранніх стадіях вивільнення інсуліну збільшується для подолання стійкості периферійних тканин. Пізніше продукція його стає недостатньою. Чітко встановлено, що ожиріння підвищує напруженість обміну речовин і сприяє виникненню ЦД [1].

Метаболічний синдром корелює з діабетом. Він зумовлює три з п'яти факторів: підвищення глюкози в крові, підвищення артеріального тиску, порушення ліпідного обміну (підвищення тригліцеридів), низький рівень холестерину лПвщ і абдомінальне ожиріння.

Початок діабету 2-го типу пов'язаний із збільшенням маси тіла та нездоровим способом життя, насамперед із нездоровою їжею та зниженою фізичною активністю.

Клінічна презентація мультиморбідна, хоча $\epsilon$ багато пацієнтів, які не мають таких типових клінічних ознак як спрага, поліурія, втрата ваги, втома та схильність до інфекцій. Часто пацієнти і медичні працівники пропускають такі важливі стани-передумови, як предіабет і метаболічний синдром, які збільшують ризик розвитку ЦД.

Процедура діагностики включає наступні пункти: 1) сімейна та особиста історія; 2) глюкоза в аналізі крові; 3) пероральний тест на толерантність до глюкози (ПТТГ); 4) повне клінічне обстеження [7].

Ретельний збір сімейного анамнезу дає дані про гіпертонічну хворобу, діабет, дисліпідемію та ранні ознаки серцево-судинних захворювань (ішемічна хвороба серця, інсульт, захворювання периферійних судин) або захворювання нирок у сім'ї пацієнта та в його найближчих родичів.

Особистий анамнез хвороби може дати інформацію про можливі симптоми діабету (полідипсія, поліурія, незрозуміла втрата ваги, схильність до інфекції (частими є баланіт і вульвовагініт), також можуть бути наявними проблеми із зором через змінену рефракцію кришталика, спричинену гіперглікемією). Для жінок мають важливе значення факти щодо маси тіла новонароджених дітей або дані про гестаційний ЦД. Потрібно розпитувати 
Огляди літератури, оригінальні дослідження, погляд на проблему, випадок з практики, короткі повідомлення щодо симптомів інших захворювань, які $є$ ускладненнями діабету і можуть виявлятися при підозрі на ЦД (насамперед, серцево-судинних і неврологічних симптомів, найчастіше периферійної сенсорної нейропатії). Необхідно отримати інформацію про спосіб життя, включаючи харчові звички, дані про зміну маси тіла, фізичну активність, куріння та вживання алкоголю. Також сімейному лікарю потрібні відповідні факти про соціальне середовище, сімейні та робочі стосунки, оскільки вони впливають на результати лікування $[4,7]$.

Лабораторними критеріями верифікації ЦД $\epsilon$ вміст глюкози натще в плазмі (без споживання калорій принаймні протягом 8 годин) $\geq 7,0$ або глюкози в плазмі через дві години після початку ПТТГ понад 11,1 ммоль/л. Дуже важливо виявити цД на стадії предіабету - гіперглікемії без діагностичних критеріїв діабету (табл. 1).

Таблиця 1. Тестові значення, що свідчать про наявність предіабету

\begin{tabular}{|l|c|c|c|}
\hline \multicolumn{1}{|c|}{ Показник } & $\begin{array}{c}\text { Експрес-визначення глюкози в } \\
\text { плазмі крові (ммоль/л) }\end{array}$ & $\begin{array}{c}\text { Глюкоза в плазмі крові } \\
120 \text { хв ПТТГ (ммоль/л) }\end{array}$ \\
\hline ПГН & $6,1-6,9$ & & - \\
\hline ПГН (ізольоване) & $6,1-6,9$ & $\mathrm{i}$ & $<7,8$ \\
\hline ПТГ (ізольоване) & $<6,1$ & $\mathrm{i}$ & $7,8-11,0$ \\
\hline ПГН і ПТГ & $6,1-6,9$ & $\mathrm{i}$ & $7,8-11,0$ \\
\hline
\end{tabular}

Примітка. ПГН - порушення глюкози натще; ПТГ - порушення толерантності до глюкози.

Для ранньої діагностики ЦД важливо не пропустити у пацієнта метаболічний синдром, пам'ятаючи про критерії його діагностики. Метаболічний синдром вимагає визначення наступних трьох факторів: 1) окружність талії: чоловіки $\geq 94$ см, жінки $\geq 80$ см; 2) тригліцериди: $\geq 1,7$ ммоль/л (або лікування гіполіпідемічними препаратами для зниження холестерину лПнЩ); 3) артеріальний тиск: систолічний $\geq 130$ мм рт. ст. або діастолічний $\geq 85$ мм рт. ст. (або лікування антигіпертензивними ліками), 4) глюкоза в крові: 5,6 ммоль/л (або лікування гіпоглікемічними препаратами). Якщо одне випадкове вимірювання глюкози в крові в будь-який час протягом доби показує вміст глюкози $\geq 11,1$ ммоль/л, це $\epsilon$ клінічною ознакою, що підтверджує ЦД [8].

Рутинне клінічне обстеження, що включає оцінку стану живлення і вимірювання артеріального тиску, $\epsilon$ мінімально достатнім для встановлення діагнозу ЦД разом із наведеними вище пунктами діагностичного процесу.

Організація медичного догляду за пацієнтами проводиться сімейним лікарем із його командоюу у вигляді планових і позапланових відвідувань. Заплановані візити відповідають рекомендаціям щодо ведення ЦД, розробленим експертними групами: Американською асоціацією діабету (ADA), Міжнародною федерацією діабету (IDF), Діагностичною групою первинної допомоги (PCDG), Сiмейними лікарями Хорватії - групою щодо ЦД (CroDiabGP) та національним стандартам кожної країни. Вони призначені для забезпечення регуляції обміну речовин і контролю над хронічними ускладненнями. Дуже важливо, щоб візити були організовані так, щоб вони були відокремлені від ведення гострих станів. В Україні раніше це називалося диспансеризацією, виконання плану якої да- вало позитивні результати із незначними фінансовими затратами держави [7].

Спостереження за хворими на ЦД планується принаймні один раз на рік або більше, якщо цього вимагає клінічний статус і регулювання програми ведення ЦД. Перший плановий візит - це коли вперше розпізнаються симптоми хвороби. Мета візиту - це низка клінічних обстежень, лабораторних досліджень і всебічна оцінка стану, яку детально висвітлено вище. Коли ЦД підтверджений, ПТГ слід перевірити у пацієнтів з дисліпідемією і в осіб старше 50 р. [4].

У програму запланованого візиту входить клінічне обстеження (маса тіла та індекс маси тіла (IMT), вимірювання артеріального тиску, обстеження щодо діабетичної стопи, направлення на експертизу очного дна), виконання низки лабораторних тестів (глюкоза в крові, НbA1с, скринінг тест-смужками білків, глюкози та кетонів у випадковому зразку сечі, ліпіди натще (загальний холестерин, холестерин лПнЩ та ЛПВЩ, тригліцериди)), печінкові ферменти (насамперед АЛТ), креатинін у сироватці крові та оцінка швидкості клубочкової фільтрації (ШКФ), мікроальбумінурія не менше двох разів на рік у разі гіпертензії). У разі виявлення нормальних результатів їх повторюють раз на рік [8].

Раз на рік сімейний лікар повинен оцінювати стан пацієнта, включаючи спосіб життя, психосоціальний статус, тенденції маси тіла, підхід до цільових значень глікемії, артеріального тиску, ліпідів (цілі можна індивідуально коригувати), наявність (контроль) хронічних ускладнень, участь пацієнта в лікуванні та прихильність пацієнта.

Позапланові візити призначені для вирішення гострих, непередбачених проблем, таких як 
Огляди літератури, оригінальні дослідження, погляд на проблему, випадок з практики, короткі повідомлення поганий контроль глікемії, гострі стрибки глікемії та непередбачені зміни клінічного стану, а також розвиток інших захворювань. Організація догляду за пацієнтом з ЦД у кабінеті повинна забезпечувати швидку і хорошу доступність лікаря або іншої адекватно освіченої особи, яка проводить обстеження

Наводимо алгоритм практичного ведення пацієнта з ЦД. Для встановлення діагнозу лікарю з його помічниками потрібно впровадити комплексні діагностичні процедури, оцінити фактори ризику, провести навчання пацієнта щодо захворювання і лікування, скласти план лікування [5].

Дуже важливим $є$ навчання пацієнта приципів дієти і способу життя. Якщо фармакологічне лікування необхідно призначити негайно, проводять швидке його призначення і виконання залежно від початкових значень глікемії та інших показників захворювання. На першому контролі медики оцінюють прихильність пацієнта, можливі побічні ефекти ліків і регуляцію метаболічного статусу. Якщо через три місяці після проведення заходів метаболічний статус все ще не врегулюється, вводять більш жорсткі заходи.

Якщо лікування комбінацією двох медикаментів не приводить до досягнення цільового метаболічного статусу необхідно направити пацієнта до діабетолога для призначення інсуліну. Допускається самостійне додаткове призначення сімейним лікарем інсуліну до попереднього лікування.

Подальшу допомогу при нерегульованому ЦД також надає сімейний лікар. Звичайний перебіг ЦД потребує додаткових заходів кожні кілька років для досягнення регуляції метаболічного синдрому, оскільки з часом відбувається поступове погіршення функції ПЗ. Потрібно оцінити, наскільки добре метаболізм регулюється, на основі рівнів НbА1c. Регуляція обміну речовин важлива для запобігання хронічним ускладненням ЦД [4].

у випадках, коли регуляція метаболічного синдрому не досягнута, спочатку доводиться сумніватися в прихильності пацієнта, а також у дотримуванні нефармакологічних заходів. Особливе значення має зниження маси тіла. Необхідно спробувати різноманітні процедури спрямування хворого на схуднення, які є доступними і прийнятними для пацієнта. Необхідне додаткове інформування і виявлення перешкод на шляху дотримання режиму харчування для досягнення цільової маси тіла [2].

Для наочності відпрацювання алгоритму діагностики і ведення пацієнта з ЦД розглянемо клінічну ситуацію. Пацієнт К., 58 років, вимірював глюкозу в крові під час відвідування свого друга і виявив 8,3 ммоль/л. У зв'язку з цим він звернувся до свого сімейного лікаря, щоб перевірити ре-

зультат. Його спрямували до лабораторії, де, крім глюкози в крові, також перевірили ліпідограму. Індекс маси тіла пацієнта - 29 кг/м², а окружність талії - 104 см. Пацієнт курить. Тричі на тиждень протягом 30-40 хвилин проявляє помірну фізичну активність. Його артеріальний тиск становить 148/92 мм рт. ст.

Два результати вимірювання глюкози натще 7,6 ммоль/л і 8,3 ммоль/л. Загальний холестерин 5,8 ммоль/л, ЛПВЩ - 1,0 ммоль/л, ЛПНЩ 4,0 ммоль/л, тригліцериди - 2,1 ммоль/л.

Оцінюючи наведене, треба зазначити, що параметри, які пацієнт вимірював під час відвідування свого друга, не можна інтерпретувати однозначно, оскільки вони можуть бути пов'язані з його прийомами їжі. Якщо у пацієнта були симптоми ЦД раніше, а вміст глюкози в крові вище 11,1 ммоль/л, ці результати будуть достатніми для діагностики ЦД, незалежно від факту зв'язку з прийомом їжі. Два тести на вміст глюкози натще в крові з результатом $\geq 7,0$ ммоль/л відповідають діагностичним критеріям ЦД. Цей пацієнт також відповідає критеріям метаболічного синдрому. ще до встановлення діагнозу можна вважати, що пацієнт має підвищений ризик розвитку ЦД на підставі наявності факторів позитивного сімейного анамнезу, абдомінального ожиріння, віку і гіперліпідемії.

Встановивши діагноз ЦД, сімейний лікар повинен призначити інші тести на час першого запланованого візиту: НbA1c, проби з сечею, креатинін, ШКФ і печінкові ферменти, скринінг-тест для діабетичної стопи. Пацієнта направляють на обстеження очного дна.

Подальше спостереження залежить від врегулювання цільового рівня глюкози. Частота спостереження в офісі залежить від стану регуляції метаболізму:

- якщо гіперглікемія регулюється, пацієнту проводять спостереження один раз на рік;

- медична сестра може перевірити пацієнта вдома між запланованими спостереженнями;

- якщо гіперглікемія не регулюється, спостереження проводяться частіше, 2-6 разів на рік; кількість спостережень коригується при змінах у лікуванні;

- ліпіди та артеріальний тиск вимірюють при необхідності, дотримуючись професійних рекомендацій;

- якщо параметри регулюються, їх контролюють раз на рік (ліпіди, робота нирок тощо).

У нашого пацієнта вміст НbА1с становив 7,3 ммоль/л, що вказує на недостатню метаболічну регуляцію щодо цільових значень глюкози. Ліпідограма показує підвищення ЛПНЩ (4,0 ммоль/л), тоді як результати аналізу креатиніну та сечі $\epsilon$ нор- 
Огляди літератури, оригінальні дослідження, погляд на проблему, випадок з практики, короткі повідомлення мальними. Повторне вимірювання артеріального тиску показує середні значення 150/98 мм рт. ст.

Якщо немедикаментозне лікування не дає результату, буде необхідно вводити ліки, зазвичай починаючи з метформіну в початковій дозі, щоб поступово його збільшувати, якщо це буде необхідно. Якщо захворювання далі буде неконтрольованим, необхідно додати інші ліки, як правило, із групи сульфонілсечовини. Якщо й далі метаболічна регуляція буде поганою (HbA1с вище 7,0%), окрім максимальної дози двох комбінацій лікарських засобів необхідно ввести інсулін або направити пацієнта до діабетолога для введення лікування інсуліном. Також потрібно вивчити, чи приймає пацієнт ліки, які можуть перешкоджати регулюванню обміну речовин. Насамперед це стосується діуретиків з групи гідрохлортіазидів у більш високих дозах (не менше 25 мг) або тривалого лікування кортикостероїдами. Лікування кортикостероїдами вимагає більш частого контролю регулювання ЦД.

Висновки. Цукровий діабет є важливою проблемою для громадського здоров'я через висо-

\section{ЛІТЕРАТУРА}

1. Сучасні класифікації та стандарти лікування захворювань внутрішніх органів. Невідкладні стани в терапії. Аналізи: нормативні показники, трактування змін / За ред. Проф. Ю. М. Мостового. - 26-те вид., змін. - Київ : Центр ДЗК, 2019. - 792 с.

2. The European EUCCLID pilot study on care and complications in an unselected sample of people with type 2 diabetes in primary care / K. J. Gorter, J. Wens, K. Khunti [et al.] // Prim. Care Diabetes. - 2010. - No. 4. - P. 17-23.

3. Prevalence of diabetes mellitus in Croatia / Ž. Metelko, I. Pavlić-Renar, T. Poljičanin [et al.] // Diabetes Res. Clin. Pract. - 2008. - No. 81. - P. 263-267.

4. Milica Katić. Family medicine / Milica Katić, Igor Švab. - Izdavač: Medicinska naklada, Zagreb. - 2017. No. 512. - P. 53-68.

\section{REFERENCES}

1. Mostovyy, Yu.M. (Ed.). (2019). Suchasni klasyfikatsii ta standarty likuvannia zakhvoriuvan vnutrishnikh orhaniv. Nevidkladni stany v terapii. Analizy: normatyvni pokaznyky, traktuvannia zmin [Modern classifications and standards of treatment of diseases of internal organs. Emergencies in therapy. Analyzes: normative indicators, interpretation of changes]. Kyiv: Tsentr DZK [in Ukrainian].

2. Gorter, K.J., Wens, J., Khunti, K., Claramunt, X.C., Topsever, P., Drivsholm, T., et al. (2010). The European EUCCLID pilot study on care and complications in an unselected sample of people with type 2 diabetes in primary care. Prim. Care Diabetes, 4, 17-23.

3. Metelko, Z., Pavlic-Renar, I., Poljicanin, T., Szirovitza, L., \& Turek, S. (2008). Prevalence of diabetes mellitus in Croatia. Diabetes Res. Clin. Pract., 81, 263-267.

кий рівень захворюваності і все більшу поширеність. Лікування пацієнтів із діабетом - це командна робота. Вона вимагає узгодження багатьох зацікавлених сторін у системі охорони здоров'я. Сімейний лікар керує та координує догляд за пацієнтом, який, з усіма його очікуваннями, бажаннями та уявленнями про хворобу і життя з нею, $є$ центром вказаного комплексу заходів. Ведення пацієнта з цукровим діабетом повинно відповідати наступним рекомендаціям: клінічна мета лікування хворих на діабет - метаболічна регуляція та профілактика хронічних ускладнень. Мета, орієнтована на пацієнта - це якість його життя і задоволеність наданою допомогою. Найважливішим $\epsilon$ удосконалення способу життя, чого досягти найскладніше. Регулярні й адекватно проведені заходи з ведення пацієнта з цукровим діабетом необхідні для мотивації до змін і наполегливості у їх проведенні і удосконаленні.

У перспективі подальшого аналізу алгоритму ведення пацієнта з цукровим діабетом за європейськими рекомендаціями плануємо розглянути методики лікування і соціальні заходи.

5. Petek D. Sladkorna bolezen tipa 2. In: Švab I, RotarPavlič D. Družinska medicina. - Ljubljana: Združenje zdravnikov družinske medicine. - 2012. - P. 9-16; 75-90.

6. Vinter-Repalust N. Obstacles which patients with type 2 diabetes meet while adhering to the therapeutic regimen in everyday life: Qualitative study / N. Vinter-Repalust, G. Petricek, M. Katic // Croat. Med. J. - 2014. - No. 45. P. 630-636.

7. Vrca Botica M. Prevencija šećerne bolesti-razine prevencije / Vrca Botica M., Pavlić Renar I. eds. Šećerna bolest u odraslih. - 1 ed. - Zagreb : Školska knjiga, 2012. - P. 20-29.

8. Vrca Botica M. Rano otkrivanje šećerne bolesti tipa 2 u obiteljskoj medicini / Vrca Botica M, Pavlić Renar I. eds. Šećerna bolest u odraslih. 1. - Zagreb : Školska knjiga, 2012. - P. 30-39.

4. Katic, M., \& Svab, I. (2017). Family medicine. Medicinska naklada. Medical edition: Zagreb.

5. Petek, D., Svab, I., \& Rotar-Pavlic, D. (2012). Sladkorna bolezen tipa 2. Druzinska medicina, 9-16, 75-90.

6. Vinter-Repalust, N., Petricek, G., \& Katic, M. (2014). Obstacles which patients with type 2 diabetes meet while adhering to the therapeutic regimen in everyday life: Qualitative Study. Croat. Med. J., 45, 630-636.

7. Vrca Botica, M., \& Pavlic Renar, I. (2012). Prevencija secerne bolesti - razine prevencije. Secerna bolest $u$ odraslih, 20-29.

8. Vrca Botica, M., \& Pavlic Renar, I. (2012). Rano otkrivanje secerne bolesti tipa 2 u obiteljskoj medicini. Secerna bolest u odraslih, 30-39. 
РЕЗЮМЕ. Из-за распространенности и хронических осложнений, которые сопровождают сахарный диабет (СД), он является значительной проблемой здравоохранения, а также финансовым и организационным бременем для людей и государства. Стоимость медицинского сопровождения пациента с СД 2-го типа в пять раз превышает средние затраты на одного пациента в популяции.

Цель - проанализировать алгоритмы диагностики и ведения пациента с сахарным диабетом 2-го типа согласно европейским протоколам (Хорватии и Словении) в целом и на примере клинической ситуации.

Обсуждение. Больные СД 2-го типа нуждаются во всесторонней помощи с соблюдением принципов ухода за пациентами с хроническими заболеваниями в семейной медицине. Управляя больным СД семейный врач выполняет следующие важные задачи: предотвратить возникновение СД с помощью мероприятий пропаганды здорового образа жизни; выявить лиц с высоким риском СД и попытаться отсрочить начало болезни; выявить СД путем раннего распознавания пациента с высоким риском его возникновения; уменьшить возникновение возможных осложнений и смертность от СД путем адекватного рационального лечения.

Выводы. Сахарный диабет является важной проблемой для общественного здоровья вследствие высокого уровня заболеваемости и все большей распространенности. Лечение пациентов с диабетом - это командная работа. Она требует согласования многих заинтересованных сторон в системе здравоохранения. Семейный врач руководит и координирует уход за пациентом, со всеми его ожиданиями, желаниями и представлениями о болезни и жизни с ней, который находится в центре данного комплекса мероприятий. Ведение пациента с сахарным диабетом должно отвечать следующим рекомендациям: клиническая цель лечения больных диабетом - метаболическая регуляция и профилактика хронических осложнений. Цель, ориентированная на пациента - это его качество жизни и удовлетворенность оказанной помощью. Важнейшим является совершенствование образа жизни, которого достичь очень сложно.

КЛЮЧЕВЫЕ СЛОВА: сахарный диабет; критерии диагностики; ведение пациентов; метаболическая регуляция; образ жизни.

\section{CURRENT ASPECTS OF DIAGNOSTICS AND MANAGEMENT OF OUTPATIENTS WITH DIABETES MELLITUS (IN THE EXPERIENCE OF CROATIA AND SLOVENIA)}

\section{@L. S. Babinets, Yu. Ya. Kotsaba \\ I. Horbachevsky Ternopil National Medical University}

SUMMARY. Due to the prevalence and chronic complications that accompany diabetes mellitus (DM), it is a significant health problem, as well as a financial and organizational burden for people and the state. Medical care for a patient with type 2 diabetes is five times more expensive than the average cost per patient in the population.

The aim - to analyze the algorithms for diagnosing and managing a patient with type 2 diabetes according to European protocols (Croatia and Slovenia) in general and on the example of the clinical situation.

Discussion. Patients with type 2 diabetes need comprehensive care in accordance with the principles of care for chronic patients in family medicine. When managing patients with diabetes, the family doctor performs the following important tasks: to prevent the occurrence of diabetes through measures to promote a healthy lifestyle; identify people at high risk of diabetes and try to delay the onset of the disease; detect diabetes by early recognition of a patient at high risk; reduce the occurrence of possible complications and mortality from diabetes through adequate management.

Conclusion. Diabetes is an important public health problem due to its high incidence and increasing prevalence. Treating patients with diabetes is a team effort. It requires the coordination of many stakeholders in the health care system. The family doctor manages and coordinates the care of the patient, who is at the center of this set of activities with all his expectations, desires and ideas about the disease and life with it. Management of a patient with diabetes mellitus should meet the following recommendations: the clinical goal of treatment of patients with diabetes is metabolic regulation and prevention of chronic complications. The goal focused on the patient is his quality of life and satisfaction with the care provided. The most important thing is to improve your lifestyle, which is the most difficult thing to achieve.

KEY WORDS: diabetes mellitus; diagnostic criteria; patient management; metabolic regulation; lifestyle.

Отримано 5.05.2020 